\title{
IQTISHODUNA
}

Vol. 17 (2), 2021

P-ISSN: 1829-524X, E-ISSN: 26143437

\section{Effect of Information Communication and Technology Use and Its Implications To Firm Performance In SMEs}

\author{
Masyhuri*1 $^{*}$ Elivia Niadianti ${ }^{2}$, Syahrul Nur Rizky ${ }^{3}$, Nurhajati ${ }^{4}$ \\ 1,2,3,4 Islamic University of Malang, Jl. Mayjen Haryono, Malang, Indonesia
}

Corresponding Author:

Nama Penulis: Masyhuri

E-mail: 2200208107@unisma.ac.id

\begin{abstract}
Research on firm performance during the Covid-19 pandemic, especially in SMEs, is important because it is related to efforts to survive in uncertain conditions due to the pandemic and the government's policy of restrictions that affect all businesses, both small and large. Therefore, this study aims to investigate the factors that can improve film performance, namely ICT use and as an update from previous research we add the innovation variable as a mediation. This research was conducted on SMEs in Malang City by involving as many as 179 samples after validating the answers to the questionnaire. Questionnaires were distributed through google forms which were distributed directly to respondents. The data is collected and then tested for validity and reliability so that the data used is of high quality. After testing the quality of the data, it is continued with hypothesis testing which is carried out using the boothstrapping method using the Smartpls 3.0 application. The results showed that ICT use had a significant effect on firm performance. Furthermore, innovation did not succeed in mediating the effect of ICT use on firm performance.
\end{abstract}

Keywords: ICT Use, Innovation, Firm Perormance, Small Medium Enterprise, Covid-19

Abstrak: Riset kinerja UKM di masa pandemi Covid-19 penting agar dapat bertahan dalam kondisi yang tidak menentu dan kebijakan pembatasan pemerintah yang berdampak pada semua pelaku usaha, baik kecil maupun besar. Oleh karena itu, penelitian ini bertujuan untuk mengetahui faktor-faktor yang dapat meningkatkan kinerja UKM yaitu penggunaan ICT dan sebagai pembaruan dari penelitian sebelumnya kami menambahkan variabel inovasi sebagai mediasi. Penelitian ini dilakukan pada UKM di Kota Malang dengan sampel sebanyak 179. Kuesioner disebarkan melalui google form. Data dikumpulkan kemudian diuji validitas dan reliabilitasnya sehingga data yang digunakan berkualitas tinggi. Setelah dilakukan pengujian kualitas data dilanjutkan dengan pengujian hipotesis yang dilakukan dengan menggunakan metode boothstrapping menggunakan aplikasi Smartpls 3.0. Hasil penelitian menunjukkan bahwa penggunaan ICT berpengaruh signifikan terhadap kinerja perusahaan. Selanjutnya, inovasi tidak berhasil memediasi pengaruh penggunaan ICT pada kinerja perusahaan.

Kata kunci: Penggunaan TIK, Inovasi, Kinerja Perusahaan, UKM, Covid 19 
Effect of Information Communication and Technology...

|Submit 29 November 2021 |Diterima 23 Oktober $2021 \mid$ Terbit 31 Oktober 2021

\section{Cara mensitasi:}

Masyhuri., Niadianti, E., Rizky, S.N., Nurhajati. (2021). The Effect of Information Communication and Technology Use on Firm Performance Mediated Innovation. Iqtishoduna. Vol. 17 (2): pp 114-125

\section{INTRODUCTION}

The Covid-19 pandemic has become a challenge as well as a threat to all countries in the world, especially Indonesia, it becomes a challenge if in responding to this pandemic always innovating within the limitations of movement and space due to the implementation of restrictions on community activities that have been in effect since January 2021. This restriction requires all companies to work from home (WFH) as much as $75 \%$ and working from the office (WFO) $25 \%$ by implementing strict health protocols. This condition is a new rule that can have an impact on the company's performance (Nasution \& Rosanti, 2020). The importance of an innovation from each individual employee as a response to the problems that occur can affect the company's performance. This innovation can be in the form of optimizing the optimal and efficient use of information, communication and technology (ICT). ICT use is the most important part in this pandemic, considering that the target of the marketing department is still running while there are limitations of movement and space, ICT use is believed to be able to improve firm performance, including increasing sales.

Several previous studies have tested ICT use to improve firm performance (DeStefano et al., 2018; Grant \& Yeo, 2018; Kumar et al., 2020; Yunis et al., 2018). Information System (IS) becomes a resource with many features related to dynamic capabilities. This stems from the fact that ICT and IS can greatly support organizations operating in dynamically and rapidly changing markets and conditions. The dynamic capability view has been used by many studies examining the contribution of ICT to enterprise value (Kindstrom et al., 2013). (Del Gaudio et al., 2020) have also found research results that ICT provides a positive role in improving performance measures. Moreover, he also finds that the overall financial stability in the banking industry is enhanced intensively with the adoption of IT and financial technology, which increases the distance to failure.

One that can affect the firm performance is innovation (Yunis et al., 2018). Innovation has been reported to be able to improve company performance. Innovation is an idea or idea in answering the problems that occur, good innovation is an idea that appears and can be applied in the company and has a positive impact on company performance such as increased sales, budget efficiency and effectiveness of working time. Therefore, the most important thing is to identify and sort out the best ideas from the 
various ideas that arise from each employee. (Chege et al., 2020; Hanelt et al., 2020; Zhang et al., 2020) states that innovation can improve company performance. In contrast to the results of research from (Darroch, 2005) who found that innovation directly had no significant effect on company performance. (Feng et al., 2020; Kijkasiwat \& Phuensane, 2020) innovation has a direct effect on company performance. There are inconsistencies from research (Darroch, 2005) there are still research gaps to be filled.

This study answer the call from (Gerguri-Rashiti et al., 2017) who conducted research using Business Environment Enterprise Performance Survey (BEEPS) data in the period 2002, 2005 and 2008. However, this study attempts to fill in the gaps of previous unresolved research, and also this research focuses on the small medium enterprise. So this study aims to examine the effect of ICT use on company performance through innovation as a mediation. This research contributes to the literature on ICT use, innovation and firm performance. First, this research contributes to the literature that explains the role of ICT use, innovation in improving firm performance during the covid 19 pandemic. Second, this study again examines the theory of dynamic capabilities of ICT use and innovation translation to be applied during the covid 19 pandemic whether it is still reliable or not.

\section{LITERATURE REVIEW}

\section{Information Communication and Technology Use}

ICT use is defined as a means to enable businesses to compete on a global scale through increased efficiency, with closer customer and supplier relationships (Alam \& Noor, 2009). The use of ICT that is not optimal can affect organizational performance. (Wade \& Hulland, 2004) states that the information system is a resource that has many dynamic features and capabilities. This is derived from the fact that ICT and IS can greatly support organizations to operate dynamically and rapidly in changing market conditions. The use of ICT plays an important role in the survival of the organization, and ICT can link supply chains, reduce costs resulting from operating processes and can improve service quality. Some indicators of the use of ICT include (Davis, 1989; Yunis et al., 2018).

\section{Innovation}

Innovation is a result-oriented measure such as the quantity of a new product that has been successfully developed for application (O'Cass \& Weerawardena, 2010). The level of innovation describes the extent to which the company can accept new ideas, analyze new ways of solving problems, think creatively about ways and methods of operation to be carried out, support and encourage to continue to create new approaches to meet market needs that are constantly moving and growing (Amabile et al., 1996; Calantone et al., 2002; De Jong \& Den Hartog, 2007). Innovation is an effort to survive in any conditions, in order to continue to increase sales, with new ways that are fresher and more adaptive even in the worst conditions. The items used to measure innovation are (Gatignon et al., 2002; Yunis et al., 2018). 


\section{Firm Performance}

Effect of Information Communication and Technology ...

Performance is the most important work attitude because it can improve the effectiveness and performance of the organization (Jankingthong \& Rurkkhum, 2012; Pawirosumarto et al., 2017; Siswanto et al., 2019) Therefore, performance is the main work attitude that is the concern of the organization or company. Firm performance can be interpreted as a managerial measure in assessing the work of employees, the work can be assessed quantitatively and qualitatively. The indicators used in performance are profitability, market share, sales growth, overall performance, and stakeholder satisfaction (Lumpkin \& Dess, 1996; Yunis et al., 2018).

\section{Hypothesis Development ICT Use and Firm Performance}

The relationship between the use of ICT on company performance as developed by (Teece \& Pisano, 2003) who argue related to the organization's ability to create new things, reshape, assimilate knowledge and skills, stay ahead in a rapidly changing competitive environment. Global market winners are those who demonstrate the company's fast and timely response, flexible product innovation, supported by effective management capabilities to coordinate and disseminate internal and external competencies, which distinguish the company from other companies, able to create something unique that is difficult to imitate. Thus, according to the theory of dynamic capabilities of the company, ICT use can affect performance. The results of research on ICT use on company performance are similar to previous research from (Aesaert \& Van Braak, 2015; DeStefano et al., 2018; Grant \& Yeo, 2018; Tarut \& Gatautis, 2014; Yunis et al., 2018). Furthermore, the hypothesis can be formulated as follows:

H1: ICT Use affect on firm performance.

\section{ICT Use and Firm Performance Mediated Innovation}

(Yunis et al., 2018) stated that the use of ICT can result in better organizational performance. Innovative companies are companies that are active in initiating a strategy for new products, services and business models to outperform the competition in the market. Furthermore, (Roberts \& Amit, 2003) said that successful innovation can become a company that has a competitive advantage and can increase profitability which is categorized as organizational performance. In addition to being the influence of ICT use, work innovation can also contribute to company performance (Wang \& Wang, 2012). Previous research found that ICT use can increase employee innovation (DeStefano et al., 2018; Irani et al., 2013; Kumar et al., 2020; Odell et al., 2020; Yunis et al., 2018) also found a positive relationship between ICT use on organizational performance including innovation. Therefore, the proposed hypothesis is as follows:

H2: Innovation mediates the relationship between ICT Use and firm performance. 


\section{RESEACRH METHOD}

This study uses three variables, namely ICT use, innovation and firm performance. Data were collected using a questionnaire from 1 (strongly disagree) to 5 (strongly agree). ICT use is measured using six scales from (Davis, 1989) namely "Frequent users of Information and Communication Technology and Information systems in organizations", "I consider myself to use my organization's technology and information systems frequently", "Integration of information and communication technology in work processes", "Using information and communication technology capabilities and information systems", "Management provides support in decision making", and "Completion of tasks using technology, information and communication as well as management information systems". Innovation is measured using 8 measurement items, namely "My company is pursuing new knowledge", "The company I work for is always looking for the latest technology", "The leadership continues to investigate in various directions", "All employees are required to explore in new areas", "The company continues to strive to make new discoveries", "Employees are required to always have breakthrough improvements", "High R\&D spending in the industry", and "High R\&D spending in the company" (Gatignon et al., 2002; Yunis et al., 2018).

The last variabel firm performance is measured using (Lumpkin \& Dess, 1996) namely "Company performance is better than competitors", "High level of efficiency in company operations", "Produktivitas perusahaan tinggi", "The enterprise market continues to grow", "High level of employee satisfaction in our company", "Customers are satisfied with our service", and "Overall, the company's performance is high and improving". The three variables above use a Likert scale measurement. This research was conducted at SME's in Malang, by distributing 250 questionnaires using Google From, but only 179 returned questionnaires. The questionnaires were distributed on 2 March - 30 June 2021. Furthermore, the data were analyzed using partial least squared structural equation modeling (PLS-SEM). The PLS-SEM is used because this research is exploratory or an extension of existing theories and the model used is relatively complex (Hair et al., 2011). Consistent with approach by (Chin \& Newsted, 1999) this study uses two steps, first testing the validity and reliability, then testing the structural model used to test the hypothesis.

\section{RESULT AND DISCUSSION Result}

The respondents in this study included 90 men (50\%) and the rest were women. This illustrates that the sample is balanced between male and female. Then, the majority of respondents aged 22-25 years 79 people (44\%), 26-29 years 51 people (28\%), 42 people (23\%) aged $30-33$ years and aged $>34$ years 7 people (5\%). So that in this study already have samples that represent from various layers of age or across generations. Then, the majority of respondents had bachelor's education 109 people (60\%), the rest 50 people $(27 \%)$ diploma and 20 high school seniors (13\%). Furthermore, the majority of work experience is $5-10$ years 81 people $(45 \%),>10$ years 55 people $(31 \%)$ and $<5$ years 43 people $(24 \%)$. This illustrates that respondents have described employees with little to much experience. The results shown in Table 1. 
Effect of Information Communication and Technology...

Table 1. Respondent Demographics

\begin{tabular}{ccccc}
\hline No. & Characteristics & Description & Frequency & $\%$ \\
\hline 1 & Gender & Male & 90 & $50 \%$ \\
& & Female & 89 & $50 \%$ \\
2 & Age & $22-25$ year & 79 & $44 \%$ \\
& & $26-29$ year & 51 & $28 \%$ \\
& & $30-33$ year & 42 & $23 \%$ \\
3 & \multirow{2}{*}{ Education } & $>34$ year & 7 & $5 \%$ \\
& & Senior High & 20 & $13 \%$ \\
& & School & 50 & $27 \%$ \\
4 & \multirow{3}{*}{4} & Diploma & 109 & $60 \%$ \\
& & Bachelor & & \\
& & $<5$ years & 43 & $24 \%$ \\
& & $5-10$ years & 81 & $45 \%$ \\
\end{tabular}

\section{Measurement Model Analysis (Outer Model)}

As explained in the method section, this study uses two steps of analysis, the first is validity and reliability testing which is included in the category of model measurement analysis. In validity testing there is discriminant validity which uses the loading factor value and discriminant validity by looking at the average variance extracted value endekata(Chin \& Newsted, 1999). The results of the validity test (ICT use, Innovation and Firm performance) show that each indicator has a loading factor value greater than 0.70 (Hair et al., $2015)$, then on the average variance extracted each variable has an AVE value of $0.623,0.670$ and 0.641 which means it is already above 0.50 . It can be said that the research instrument is valid. In reliability testing, composite reliability (CR) values can be used and in this study it is known that the CR value of the ICT use variable is 0.908, Innovation is 0.942 and Firm performance is 0.926 , which means that each variable is reliable because the CR value is above 0.70 (Hair et al., 2017). It can be concluded that the instrument is reliable. For more details, see table 2 below. 
Masyhuri, Elivia Niadianti, Syahrul Nur Rizky, Nurhajati

Table 2. Data Quality Test

\begin{tabular}{|c|c|c|c|c|c|c|}
\hline Variable & Item & $\begin{array}{l}\text { Loading } \\
\text { Factor }\end{array}$ & Result & $\begin{array}{l}\text { Composite } \\
\text { Reliability }\end{array}$ & AVE & Result \\
\hline \multirow[t]{6}{*}{ ICT Use } & ICT1 & 0.764 & \multirow[t]{6}{*}{ Valid } & \multirow[t]{6}{*}{0.908} & \multirow[t]{6}{*}{0.623} & \multirow[t]{6}{*}{ Reliable } \\
\hline & ICT2 & 0.816 & & & & \\
\hline & ICT3 & 0.747 & & & & \\
\hline & ICT4 & 0.772 & & & & \\
\hline & ICT5 & 0.832 & & & & \\
\hline & ICT6 & 0.803 & & & & \\
\hline \multirow[t]{8}{*}{ Innovation } & INOV1 & 0.824 & \multirow[t]{8}{*}{ Valid } & \multirow[t]{8}{*}{0.942} & \multirow[t]{8}{*}{0.670} & \multirow[t]{8}{*}{ Reliable } \\
\hline & INOV2 & 0.741 & & & & \\
\hline & INOV3 & 0.763 & & & & \\
\hline & INOV4 & 0.906 & & & & \\
\hline & INOV5 & 0.835 & & & & \\
\hline & INOV6 & 0.767 & & & & \\
\hline & INOV7 & 0.848 & & & & \\
\hline & INOV8 & 0.850 & & & & \\
\hline Firm & PERFOR & 0.783 & \multirow[t]{14}{*}{ Valid } & \multirow[t]{14}{*}{0.926} & \multirow[t]{14}{*}{0.641} & \multirow[t]{14}{*}{ Reliable } \\
\hline \multirow[t]{13}{*}{ Performance } & M1 & 0.895 & & & & \\
\hline & PERFOR & 0.811 & & & & \\
\hline & M2 & 0.783 & & & & \\
\hline & PERFOR & 0.788 & & & & \\
\hline & M3 & 0.819 & & & & \\
\hline & PERFOR & 0.714 & & & & \\
\hline & M4 & & & & & \\
\hline & PERFOR & & & & & \\
\hline & M5 & & & & & \\
\hline & PERFOR & & & & & \\
\hline & M6 & & & & & \\
\hline & PERFOR & & & & & \\
\hline & M7 & & & & & \\
\hline
\end{tabular}

Structural Model Analysis (Inner Model)

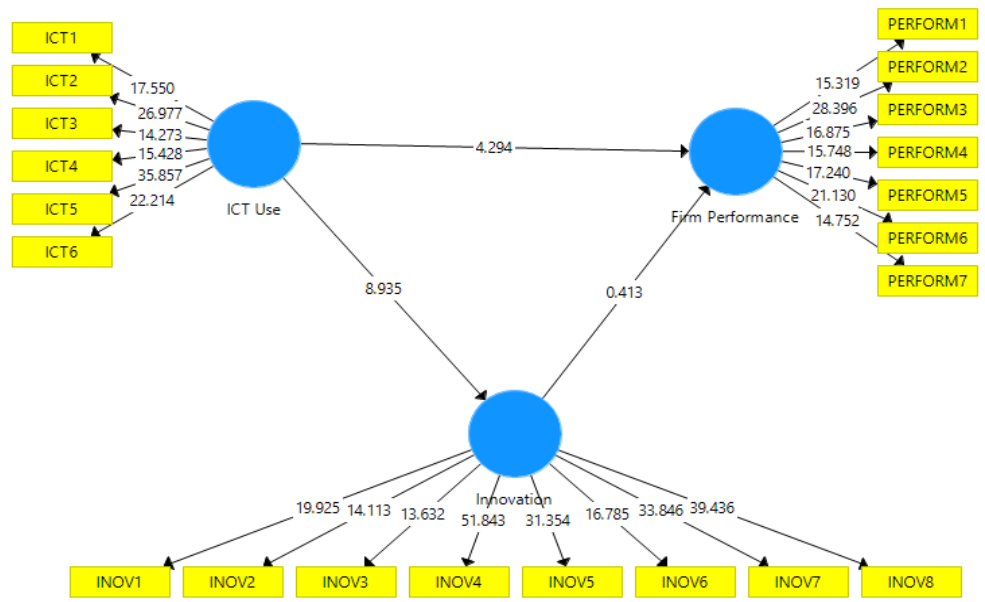

Figure 1. Structural equation modeling results 
Effect of Information Communication and Technology...

For hypothesis testing using structural model testing as shown in Figure 3 above, the image is the result of boothstrapping testing of the Smartpls 3.0 application. The picture above shows that the research has several hypotheses that will be verified through empirical data obtained directly from the field. ICT use has a direct effect on firm performance and the role of innovation in mediating the effect of ICT use on firm performance is the final hypothesis. In the boothstrapping analysis with 5000 resampling we followed (Hair et al., 2017)

Table 3. Direct Effect

\begin{tabular}{|c|c|c|c|c|c|}
\hline & Direct Effect & $\begin{array}{l}\text { Sample } \\
\text { Mean }\end{array}$ & $\begin{array}{c}\mathrm{T}- \\
\text { Statistic }\end{array}$ & $\begin{array}{c}\text { T- } \\
\text { Table }\end{array}$ & Result \\
\hline $\mathrm{H}_{1}$ & ICT Use $\rightarrow$ Firm Performance & 0.329 & 4.294 & & Accepted \\
\hline $\mathrm{H}_{2}$ & ICT Use $\rightarrow$ Innovation & 0.391 & 8.935 & 1.96 & Accepted \\
\hline $\mathrm{H}_{3}$ & $\begin{array}{l}\text { Innovation } \rightarrow \\
\text { Performance }\end{array} \rightarrow$ & -0.030 & 0.413 & & Rejected \\
\hline
\end{tabular}

Tables 3 and 4 are the results of the research in brief, it can be explained that the direct effect of ICT use on firm performance $(t=4.294>1.96)$, then the effect of ICT use on innovation $(t=8.935>1.96)$ and the direct effect of innovation and firm performance $(t=0.413<1.96)$. There is one hypothesis that is not in line with expectations, namely innovation on firm performance. Furthermore, table 4 is used to determine the role of the mediating variable (innovation) in the influence of ICT use on firm performance $(t=0.403<1.96)$, it is concluded that the hypothesis is rejected.

Table 4. Indirect Effect

\begin{tabular}{lc}
\hline \multicolumn{1}{c}{ Hypothesis } & Mediation \\
\hline Indirect Effect (T-Statistic) & Innovation \\
ICT Use and Firm Performance & 0.403 \\
\hline
\end{tabular}

\section{Discussion}

As predicted earlier, ICT use can improve firm performance on SMes. This study supports several previous studies that have tested ICT use in improving organizational performance (DeStefano et al., 2018; Grant \& Yeo, 2018; Kumar et al., 2020; Yunis et al., 2018). This research has succeeded in empirically proving that the optimal use of ICT is able to help SMEs more quickly transform in an uncertain situation, especially during the COVID-19 pandemic that has hit Indonesia and various countries in the world since late 2019. The pandemic conditions that led to a policy of limiting community activities made people's purchasing power decrease drastically. The challenges are even greater for small and medium-sized business owners in order to survive in the midst of uncertainty and worsening economic conditions. However, based on empirical data from the field, it can be seen that entrepreneurs have been using information, communication and 
technology facilities to increase sales. One way to do this is by integrating ICT in the work process, from sales promotion, order processing to delivery, all using ICT. In promotion, business owners maximize the display of the dynamic capabilities of their website and social media as a marketing avenue to increase company value (Kindstrom et al., 2013).

The results of this study also support (Del Gaudio et al., 2020) who have found research results that ICT provides a positive role in improving performance measures. The relationship between the use of ICT on company performance is in accordance with the opinion of (Teece \& Pisano, 2003) who argue related to the organization's ability to create new things, reshape, assimilate knowledge and skills, stay ahead in a rapidly changing competitive environment. The samples in this study can be said to be market winners because they show a fast and timely response from the company, flexible product innovations, supported by effective management capabilities to coordinate and disseminate internal and external competencies, which distinguish the company from other companies, are able to create something unique that is difficult to imitate. Thus, the results of this study empirically support the theory of dynamic capabilities of companies, ICT use can affect performance.

Then the mediating role of innovation in this study is rejected, this illustrates that innovation in SMEs in Malang cannot significantly improve firm performance. This is different from the results of previous research from (Chege et al., 2020; Hanelt et al., 2020; Zhang et al., 2020) which states that innovation can improve company performance. However, the results of this study support the results of research from (Darroch, 2005) who found that innovation directly had no significant effect on company performance. Conditions in the field show that some SME owners still have few innovations in the form of pursuing new knowledge, using the latest technology, demands for employees to innovate, low research and development budgets are also indicators that make innovation in SMEs unable to improve firm performance significantly. significant. The results of this study have also filled the gaps of the research (Gerguri-Rashiti et al., 2017) by including innovation as mediation as renewal.

\section{CONCLUSION}

This study found facts in the field that ICT use can significantly improve firm performance. Furthermore, it can be seen that entrepreneurs have been using information, communication and technology facilities to increase sales. One way to do this is by integrating ICT in the work process, from sales promotion, order processing to delivery, all using ICT. In promotion, business owners maximize the display of the dynamic capabilities of the website and social media. in the field there is also a fact that innovation is not proven to improve firm performance. Some SME owners are still few who have innovation in the form of pursuing new knowledge, using the latest technology, the demands on employees to innovate, low research and development budgets are also indicators that make innovation in SMEs unable to improve firm performance. Furthermore, suggestions for SME business owners, especially in the city of Malang, are to continue trying to survive amid 
Effect of Information Communication and Technology... the uncertainty of Indonesia's current economic conditions due to the pandemic, the researcher understands that with the restriction policy by the government, all businesses, both large and small, are affected, but based on some findings from research previously it was clear that innovation was one of the paths that each business owner could take, this innovation could be in the form of targeting employees to continue to provide their best ideas, increasing the R\&D budget, besides that business owners must continue to look for the latest technology and use it in the work process, continue to pursue new knowledge from seminars, training and so on in an effort to enrich knowledge. So that business owners and employees can work together in terms of innovation, complementing each other so that innovation can significantly improve firm performance.

\section{REFERENCES}

Aesaert, K., \& Van Braak, J. (2015). Gender and socioeconomic related differences in performance based ICT competences. Computers \& Education, 84, 8-25.

Alam, S. S., \& Noor, M. K. M. (2009). ICT adoption in small and medium enterprises: An empirical evidence of service sectors in Malaysia. International Journal of Business and Management, 4(2), 112-125.

Amabile, T. M., Conti, R., Coon, H., Lazenby, J., \& Herron, M. (1996). Assessing the work environment for creativity. Academy of Management Journal, 39(5), 1154-1184.

Calantone, R. J., Cavusgil, S. T., \& Zhao, Y. (2002). Learning orientation, firm innovation capability, and firm performance. Industrial Marketing Management, 31(6), 515-524.

Chege, S. M., Wang, D., \& Suntu, S. L. (2020). Impact of information technology innovation on firm performance in Kenya. Information Technology for Development, 26(2), 316-345.

Chin, W. W., \& Newsted, P. R. (1999). Structural equation modeling analysis with small samples using partial least squares. Statistical Strategies for Small Sample Research, 1(1), 307-341.

Darroch, J. (2005). Knowledge management, innovation and firm performance. Journal of Knowledge Management.

Davis, F. D. (1989). Perceived usefulness, perceived ease of use, and user acceptance of information technology. MIS Quarterly, 319-340.

De Jong, J. P., \& Den Hartog, D. N. (2007). How leaders influence employees' innovative behaviour. European Journal of Innovation Management.

Del Gaudio, B. L., Porzio, C., Sampagnaro, G., \& Verdoliva, V. (2020). How do mobile, internet and ICT diffusion affect the banking industry? An empirical analysis. European Management Journal.

DeStefano, T., Kneller, R., \& Timmis, J. (2018). Broadband infrastructure, ICT use and firm performance: Evidence for UK firms. Journal of Economic Behavior \& Organization, 155, 110-139.

Feng, C., Ma, R., \& Jiang, L. (2020). The impact of service innovation on firm performance: A meta-analysis. Journal of Service Management. 
Gatignon, H., Tushman, M. L., Smith, W., \& Anderson, P. (2002). A structural approach to assessing innovation: Construct development of innovation locus, type, and characteristics. Management Science, 48(9), 1103-1122.

Gërguri-Rashiti, S., Ramadani, V., Abazi-Alili, H., Dana, L.-P., \& Ratten, V. (2017). ICT, innovation and firm performance: The transition economies context. Thunderbird International Business Review, 59(1), 93-102.

Grant, D., \& Yeo, B. (2018). A global perspective on tech investment, financing, and ICT on manufacturing and service industry performance. International Journal of Information Management, 43, 130-145.

Hair, J. F., Ringle, C. M., \& Sarstedt, M. (2011). PLS-SEM: Indeed a silver bullet. Journal of Marketing Theory and Practice, 19(2), 139-152.

Hanelt, A., Firk, S., Hildebrandt, B., \& Kolbe, L. M. (2020). Digital M\&A, digital innovation, and firm performance: An empirical investigation. European Journal of Information Systems, 1-24.

Irani, Z., Arvanitis, S., Loukis, E., \& Diamantopoulou, V. (2013). The effect of soft ICT capital on innovation performance of Greek firms. Journal of Enterprise Information Management.

Jankingthong, K., \& Rurkkhum, S. (2012). Factors affecting job performance: A review of literature. Humanities, Arts and Social Sciences Studies (FORMER NAME SILPAKORN UNIVERSITY JOURNAL OF SOCIAL SCIENCES, HUMANITIES, AND ARTS), 115-128.

Kijkasiwat, P., \& Phuensane, P. (2020). Innovation and firm performance: The moderating and mediating roles of firm size and small and medium enterprise finance. Journal of Risk and Financial Management, 13(5), 97.

Kindström, D., Kowalkowski, C., \& Sandberg, E. (2013). Enabling service innovation: A dynamic capabilities approach. Journal of Business Research, 66(8), 1063-1073.

Kumar, A., Singh, R. K., \& Modgil, S. (2020). Exploring the relationship between ICT, SCM practices and organizational performance in agri-food supply chain. Benchmarking: An International Journal.

Lumpkin, G. T., \& Dess, G. G. (1996). Clarifying the entrepreneurial orientation construct and linking it to performance. Academy of Management Review, 21(1), 135-172.

Nasution, I., \& Rosanti, R. (2020). Pengaruh Bekerja Dari Rrumah (Work From Home) Terhadap Kinerja Karyawan BPKP. Jurnal Ilmiah Akuntansi Budgeting, 1(1), 9-14.

O'Cass, A., \& Weerawardena, J. (2010). The effects of perceived industry competitive intensity and marketing-related capabilities: Drivers of superior brand performance. Industrial Marketing Management, 39(4), 571-581.

Odell, B., Cutumisu, M., \& Gierl, M. (2020). A scoping review of the relationship between students' ICT and performance in mathematics and science in the PISA data. Social Psychology of Education, 1-33.

Pawirosumarto, S., Sarjana, P. K., \& Muchtar, M. (2017). Factors affecting employee performance of PT. Kiyokuni Indonesia. International Journal of Law and Management. 
Effect of Information Communication and Technology...

Roberts, P. W., \& Amit, R. (2003). The dynamics of innovative activity and competitive advantage: The case of Australian retail banking, 1981 to 1995. Organization Science, 14(2), 107-122.

Shah, S. Z. A., \& Hussain, Z. (2012). Impact of ownership structure on firm performance evidence from non-financial listed companies at Karachi Stock Exchange. International Research Journal of Finance and Economics, 84, 6-13.

Siswanto, S., Supriyanto, A., Ni'mah, U., Asnawi, N., \& Wekke, I. (2019). Does a workload influence the performance of bank employees? Management Science Letters, 9(5), 639-650.

Supriyanto, A. S., Ekowati, V. M., Idris, I., Susminingsih, S., \& Iswanto, B. (2020). Leadership styles as a predictor of the voluntary work behaviors of bank employees. IJEM International Journal of Economics and Management, 14(1), 1-11.

Supriyanto, A. S., \& Maharani, V. (2013). Metodologi Penelitian Manajemen Sumber Daya Manusia Teori, Kuesioner, dan Analisis Data. Cetakan II.

Tarute, A., \& Gatautis, R. (2014). ICT impact on SMEs performance. ProcediaSocial and Behavioral Sciences, 110, 1218-1225.

Teece, D., \& Pisano, G. (2003). The dynamic capabilities of firms. In Handbook on knowledge management (pp. 195-213). Springer.

Wade, M., \& Hulland, J. (2004). The resource-based view and information systems research: Review, extension, and suggestions for future research. MIS Quarterly, 107-142.

Wang, Z., \& Wang, N. (2012). Knowledge sharing, innovation and firm performance. Expert Systems with Applications, 39(10), 8899-8908.

Yunis, M., Tarhini, A., \& Kassar, A. (2018). The role of ICT and innovation in enhancing organizational performance: The catalysing effect of corporate entrepreneurship. Journal of Business Research, 88, 344-356.

Zhang, Y., Hult, G. T. M., Ketchen, D. J., \& Calantone, R. J. (2020). Effects of firm-, industry-, and country-level innovation on firm performance. Marketing Letters, 31(2), 231-245. 